\title{
Peran Dukungan Sosial dan Regulasi Emosi Terhadap Resiliensi Keluarga Penderita Skizofrenia
}

\author{
Daisy Prawitasari Poegoeh ${ }^{1}$ \\ RSJ Dr. Radjiman Wediodiningrat, Lawang - Malang \\ Hamidah $^{2}$ \\ Dept. Psikologi Klinis dan Kesehatan Mental Fak. Psikologi Universitas Airlangga, Surabaya
}

\begin{abstract}
The research examined the relationship between social support, emotion regulation and family resilience of schizophrenic patients. The method used in this research was quantitative method by using questionnaires to survey parents of schizophrenic patient. Questionnaires used in this research were Social Support Index (SSI), Cognitive Emotion Regulation Questionnaire (C-ERQ) and Family Resilience Assessment Scale (FRAS). Result indicated that there was a significant relationship between social support, emotional regulation and family resilience in the sample of 60 schizophrenic patients' parents. It indicated through multiple coefficient $(R=0.596, p<0.05)$. Coefficient of determination $\left(R^{2}=0.355, p<0.05\right)$ revealed that both variable influenced family resilience by $35.5 \%$. Social support contributed $20.9 \%$, while emotional regulation had $14.6 \%$ contribution to family resilience of schizophrenic patients. It suggested that the practitioners for family intervention with emphasis of how to get social support, especially networking support and regulating emotion in order to increase families of schizophrenic patients' resilience.
\end{abstract}

Key words: emotional regulation, family resilience, schizophrenia, social support.

\begin{abstract}
Abstrak.
Penelitian dilakukan untuk mengetahui hubungan antara dukungan sosial, regulasi emosi dan resiliensi keluarga penderita skizofrenia. Metode penelitian menggunakan metode kuantitatif dengan menggunakan kuesioner Social Support Index (SSI), Cognitive Emotion Regulation Questionnaire (CERQ) dan Family Resilience Assessment Scale (FRAS). Hasil penelitian adalah adanya hubungan yang signifikan antara dukungan sosial, regulasi emosi dan resiliensi pada 60 orangtua pasien yang menjalani rawat inap ulang dengan diagnosis skizofrenia. Hasil dari keeratan hubungan tersebut ditunjukkan melalui nilai koefisien regresi linier berganda $(R=0.596, p<0.05)$. Koefisien determinasi $\left(R^{2}=0.355, p<0.05\right)$ menunjukkan secara bersama-sama variable dukungan sosial dan regulasi emosi dapat mempengaruhi variabel resiliensi keluarga sebesar $35.5 \%$. Sumbangan relatif dukungan sosial terhadap resiliensi keluarga adalah sebesar $20.9 \%$ dan sumbangan relatif regulasi emosi sebesar 14.6\%. Temuan dari penelitian ini menunjukkan besarnya peran dukungan sosial dan regulasi emosi terhadap resiliensi keluarga penderita skizofrenia, sehingga para praktisi dapat memfokuskan pada faktor protektif untuk meningkatkan resiliensi keluarga.
\end{abstract}

Kata Kunci: dukungan sosial, regulasi emosi, resiliensi keluarga, skizofrenia.

Korespondensi: ${ }^{1}$ RSJ Dr. Radjiman Wediodiningrat. Jln. xxxx, Lawang - Malang, ${ }^{2}$ Departemen Psikologi Klinis dan Kesehatan Mental Fakultas Psikologi Universitas Airlangga. Jln. Airlangga 4-6. Surabaya. Telp. (031) 5032770, Email: ${ }^{1}$ daisy.prawita-p-p-11@psikologi.unair.ac.id. ²hamidah@psikologi.unair.ac.id 


\section{PENDAHULUAN}

Berdasarkan data yang disampaikan pada konferensi tahunan The American Psychiatric Association (APA) di Miami Florida, Mei 1995, disebutkan bahwa angka penderita Skizofrenia cenderung meningkat menjadi 1 per 100 penduduk. Selanjutnya dikemukakan, bahwa setiap tahun 300.000 penderita Skizofrenia mengalami kekambuhan. Menurut data World Health Organization (WHO), masalah gangguan kesehatan mental di seluruh dunia memang sudah menjadi masalah yang sangat serius. WHO (2001) menyatakan paling tidak ada satu dari empat orang di dunia mengalami gangguan kesehatan mental dan memperkirakan ada sekitar 450 juta orang di dunia mengalami gangguan kesehatan mental. Berdasarkan laporan WHO tahun 2005 menyatakan bahwa terdapat lima gangguan mental terbanyak di dunia, yaitu depresi unipolar (11.8\%), alcohol used disorder (3.3\%), skizofrenia (2.8\%), depresi bipolar (2.4\%), dan demensia (1.4\%) (WHO, 2005).

Skizofrenia berasal dari kata schizein (pecah-belah) dan phren (otak). Bleuler (1939 dalam Nevid \& Rathus, 2003) menyebutkan istilah skizofrenia yang secara tepat menonjolkan gejala utama dari gangguan ini, yaitu otak yang terpecah belah. Artinya, ada keretakan atau pemisahan antara proses pikir, respon-respon perasaan atau afektif dan perilaku. Penyebab yang dapat menimbulkan patofisiologis dari skizofrenia sampai saat ini belum dapat diketahui, namun ada beberapa faktor risiko yang dapat menyebabkan munculnya skizofrenia. Skizofrenia kemungkinan merupakan suatu kelompok gangguan dengan penyebab yang berbeda dan secara pasti memasukkan pasien yang gambaran klinis, respon pengobatan, dan perjalanan penyakitnya bervariasi. Kaplan, dkk. (1997) menjelaskan tentang etiologi skizofrenia atara lain diatesis-stress model, faktor biologis, faktor genetik, psikogenesis, teori pembelajaran, teori keluarga dan teori sosial.

Hasil sebuah survei yang dilakukan oleh The Indonesian Psychiatric Epidemologic (2004) menyebutkan sekitar $18.5 \%$ orang dewasa pernah mengalami gangguan mental, baik ringan maupun parah dan sebagian besarnya adalah skizofrenia. Sebagian besar penderita skizofrenia merupakan individu dalam usia produktif, tetapi mereka cenderung ditelantarkan. Survei yang dilakukan oleh Kementerian Sosial Republik Indonesia (2008) menunjukkan dari sekitar 650 ribu penderita gangguan mental berat di Indonesia dan sekitar 30 ribu penderita Skizofernia dipasung keluarganya. Alasan pemasungan agar penderita tidak membahayakan orang lain dan menimpakan aib pada keluarganya.

Survei Kesehatan Rumah Tangga (1995) yang dilakukan oleh Badan Penelitian dan Pengembangan Kesehatan menunjukkan prevalensi gangguan mental emosional pada anggota rumah tangga dewasa (diatas 15 tahun) adalah 264 per 10oo. Pada anak remaja (5-15 tahun) adalah 104 per 1000 . Prevalensi di atas 100 per 1000 anggota rumah tangga dianggap sebagai suatu permasalahan kesehatan yang penting. Kementerian Kesehatan lewat Riset Kesehatan Dasar (Riskesdas) (2007) mencatat penderita gangguan mental berat adalah sebanyak 0.46\% dari populasi nasional. Angka tersebut setara dengan 1.093.150 penduduk mengalami gangguan mental berat, termasuk skizofrenia dimana setiap tahunnya sebanyak $35 \%$ kambuh, sedangkan 19 juta orang lainnya menderita gangguan mental ringan hingga sedang, yaitu total populasi beresiko yang menerima perawatan yang memadai (Riskesdas, 2007).

Saat ini, Kementerian Kesehatan Republik Indonesia giat mengampanyekan Indonesia Bebas Pasung 2014, namun target itu kemudian direvisi menjadi 2019 dengan pertimbangan bahwa menurut Riset Kesehatan Dasar 2007, dari total populasi 1.09 juta orang ternyata hanya 
38 ribu (3.5\%) yang terlayani dengan baik. Selama program sosialisasi bebas pasung itu, Kementerian Kesehatan sudah mendapatkan sebanyak 4.329 pasien gangguan mental yang dipasung, yang tersebar di 19 provinsi. Skizofrenia menimbulkan beban bagi keluarga baik karena penyakitnya maupun jangka waktu kesembuhan. Menurut perspektif Kraepelin, skizofrenia adalah suatu penyakit yang cenderung memburuk. Meskipun demikian, sejalan dengan perkembangan waktu, semakin banyak penelitian yang memberikan bukti empiris tentang kesembuhan skizofrenia (Harding, dkk. dalam Subandi, dalam penerbitan).

Menurut Scharff \& Scharff (1991 dalam Day, 2007) keluarga adalah suatu sistem yang berisi sejumlah relasi yang berfungsi secara unik. Definisi tentang keluarga menegaskan bahwa hakikat dari keluarga adalah relasi yang terjalin antara individu yang menentukan komponen-komponennya. Bila ada sesuatu menimpa atau dialami oleh salah satu anggota keluarga, dampaknya mengenai seluruh anggota keluarga yang lain. Penelitian yang dilakukan oleh Gibbons (1988) menyatakan bahwa diperkirakan sejumlah 50\%80\% penderita skizofrenia maupun gangguan psikotik lainnya yang berhubungan secara rutin dengan keluarga yang juga menjadi caregiver-nya, maka dalam keluarga tersebut akan menunjukkan adanya tingkat beban yang tinggi terkait dengan merawat anggota keluarganya yang mengalami skizofrenia (McDonnel, dkk., 2003).

Systemic view of illness menyebutkan bahwa apabila ada salah satu anggota keluarga yang mengalalami sakit, maka semua anggota keluarga akan terpengaruh. Apabila kesulitan dalam perawatan itu tinggi maka anggota keluarga yang lain juga akan merasakan beban yang berat atau sakit. Apabila caregiver tersebut sakit, maka pasien yang sedang sakit itu akan menghadapi kesulitan lebih besar untuk penyembuhan. Pandangan sistemik dari penyakit ini berarti memahami pengaruh dari sakit yang dirasakan pasien terhadap sistem keluarga dan memahami dampak sistem keluarga terhadap pasien dan outcomenya (Heru \& Dreary, 2011).

Perawatan penderita skizofrenia dalam keluarga adalah tanggung jawab yang berat. Berdasarkan hasil survei yang dilakukan oleh National Family Caregiver Association di Amerika Serikat (1997), 58\% anggota keluarga yang merawat penderita skizofrenia mengalami gejala depresi yang signifikan dan 34\% diantaranya berpendapat mereka tidak menerima bantuan dari anggota keluarga yang lain maupun teman-teman di lingkungan sosialnya. Hwu (1998 dalam Wei, 2008) dalam penelitiannya mengenai caregiver penderita skizofrenia di Taiwan menyatakan adanya stres emosional berat, yaitu $64.4 \%$ menyangkal keberadaan orang dengan skizofrenia di tengah keluarga mereka dan $45.6 \%$ menarik diri dari lingkungan karena adanya penderita skizofrenia dalam keluarga mereka. Temuan ini merefleksikan hubungan kausal antara depresi dan perawatan penderita skizofrenia, membuktikan bahwa keluarga dari penderita skizofrenia adalah populasi yang rentan, mengalami stres dan menghadapi stigma sosial dan karenanya memiliki suatu kebutuhan yang mendesak.

Kondisi pasien skizofrenia menjadi sumber stres bagi anggota keluarganya. Seperti halnya penyakit berat lainnya. Adanya penderita skizofrenia dalam keluarga dipandang sebagai musibah oleh seluruh keluarga tersebut (Finkelman, 200o dalam Gonzales-Torres, 2010). Munculnya berbagai gejala dari penderita dapat memberikan dampak tersendiri bagi keluarga. Keberadaan penderita di tengahtengah keluarga memberikan beban secara fisik dan psikis untuk setiap anggota keluarga lain yang ada di dalamnya, terutama orang tua (Jones \& Hayward, 2005 dalam Jones \& Pasley, 2009). Keluarga penderita skizofrenia juga akan menderita karena banyaknya sumber stres yang 
terjadi, mengalami kesulitan, dan kurangnya bantuan dari pelayanan kesehatan mental (Song, dkk., 1997 dalam Wei, 2008). Perawatan dan dukungan pada penderita schizofrenia bisa mempengaruhi well being dan kesehatan mental dari anggota keluarga yang lain (Cuijpers \& Stam, 200o dalam Wei, 2008).

Hubungan antara penderita skizofrenia dan keluarganya dapat terganggu karena adanya perilaku negatif dan pola komunikasi yang kacau. Pengaruh ini akan semakin parah apabila gaya komunikasi dan sikap keluarga penderita cenderung negatif. Hal ini akan berpengaruh secara negatif terhadap proses penyembuhan penderita skizofrenia. Keluarga, sebaliknya, juga dapat menjadi sumber resiko bagi kerentanan penderita skizofrenia. Meta analisis dari 27 penelitian (Butzlaff \& Holey, 1998) menyebutkan bahwa ekspresi emosi tinggi anggota keluarga yang dimanifestasikan dengan munculnya komentar-komentar yang kritis, sinis, tajam, dan keterlibatan emosional yang berlebihan yang muncul dalam kata-kata spontan anggota keluarga, telah berhubungan dengan keadaan/relaps penderita skizofrenia dan timbulnya symptom positif yang lebih kuat dalam 6 bulan follow-up (dalam Schloser, dkk., 2010).

Resiliensi didefinisikan sebagai kemampuan untuk beradaptasi, mengatasi masalah, bertahan dan melenting dari musibah dalam kondisi fungsional (Walsh 1998; Walsh, 2003, Deegan, 2005 dalam Plump, 2011). Resiliensi keluarga adalah tingkat resiliensi yang terkait dengan hubungan yang kompleks dan faktor-faktor lingkungan (Van Breeda, 2003). Dalam orientasi sistem biopsikososial, resiko dan resiliensi dipandang dalam suatu pengaruh berulang yang melibatkan individu, keluarga dan sistem sosial yang lebih besar (Walsh, 2003). Resiliensi keluarga meliputi kemampuan untuk mengembangkan ketrampilan interpersonal yang adaptif, misalnya membedakan orang dengan sakitnya, dan adanya kualitas keluarga yang positif, misalnya adanya penerimaan secara mutual dan keterlibatan yang empatik (Heru \& Dreary, 2011).

Keluarga sebagai social support system juga dapat dikatakan sebagai sarana terdekat bagi seseorang yang membutuhkan dukungan sosial. Dukungan sosial dalam keluarga dapat menurunkan tingkat kerentanan stres dan juga meningkatkan kemampuan bagi penderita skizofrenia untuk bisa menghadapi dan mengatasi masalah yang menimbulkan stres (Chow, 2011). Persepsi terhadap dukungan sosial adalah indikator positif pada beban keluarga yang disebabkan oleh penderita skizofrenia, merupakan peran kunci dan berkontribusi secara signifikan terhadap kesembuhan gangguan mental (Thoits, 1995 dalam Chow, 2011). Pemaknaan terhadap suatu kejadian musibah dengan sikap yang optimis akan memberikan respon yang positif terhadap kejadian tersebut dan membantu melakukan penyesuaian diri dan pemecahan masalah (Silderberg, 2001).

Regulasi emosi adalah fungsi yang sangat signifikan dalam kehidupan manusia. Regulasi emosi sendiri adalah bentuk kontrol yang dilakukan seseorang terhadap emosi yang dimilikinya. Setiap hari individu akan terus menerus terpapar pada ragam stimuli yang berpotensi untuk membangkitkan emosi. Oleh sebab itu, reaksi emosional yang tidak sesuai, ekstrim atau tidak terkontrol akan menggganggu fungsi individu dalam masyarakat, sehingga diperlukan adanya regulasi emosi setiap waktu (Gross \& John, 2003). Individu biasanya akan menunjukkan fleksibilitas dalam mengelola keadaan emosional yang ekstrim, tetapi tidak menutup kemungkinan adanya orang-orang yang kekurangan ketrampilan dasar atau kesadaran akan adanya regulasi emosi, atau terganggu disebabkan karena alasan klinis atau perkembangan. Sebagai contoh, orang-orang yang mengalami gangguan di otak, trauma atau kondisi psikiatrik dan psikologis dapat menjadikan ia tidak mampu melakukan 
regulasi emosi.

Orang-orang yang seperti itu akan tergolong sebagai poor self regulator, yaitu orang- orang yang mungkin marah atau meletakkan frustrasinya pada orang lain atau pada dirinya sendiri dan menunjukkan ekspresi wajah yang berlawanan dengan normatif pada situasi tersebut. Mereka tidak mampu mengontrol emosinya dengan baik. Regulasi dapat mempengaruhi perilaku dan pengalaman seseorang. Hasil dari regulasi dapat berupa perilaku yang ditingkatkan, dikurangi atau dihambat dalam ekspresinya. Menurut pandangan psikologi evolusi, regulasi emosi sangat diperlukan karena beberapa bagian dari otak manusia menginginkan untuk melakukan sesuatu pada situasi tertentu, sedangkan bagian lainnya menilai bahwa rangsangan emosional ini tidak sesuai dengan situasi saat itu, sehingga membuat seseorang melakukan sesuatu yang lain atau tidak melakukan sesuatu pun (Gross, 1999). Reiss dan Patrick (1996 dalam Kring \& Sloan, 2010) menyatakan bahwa ada perbedaan individual dalam reaksi emosional yang mempengaruhi bagaimana seseorang bisa mencapai keadaan emosi yang sejahtera setiap harinya. Menurut Reiss dan Patrick (1996), regulasi emosi yang ditampilkan oleh setiap individu dapat menentukan kesejahteraan emosi dalam setiap interaksi sosial.

Berdasarkan penjelasan pada latar belakang diatas, terlihat pentingnya resiliensi keluarga agar keluarga dapat menjadi sistem pendukung bagi penderita skizofrenia. Asumsi yang muncul adalah bahwa munculnya resiliensi dalam keluarga penderita skizofrenia disebabkan karena adanya dukungan sosial dari keluarga dan teman-teman di lingkungan, sehingga dapat membantu keluarga tersebut mengatasi stres dan permasalahan yang dihadapi (Fischer \& Corcoran, 2007).

Hal kedua yang diasumsikan mempengaruhi resiliensi keluarga adalah kemampuan individu dalam keluarga tersebut melakukan regulasi emosi. Strategi regulasi tersebut akan meningkatkan emosi positif dan dapat mengurangi pengaruh emosi negatif ketika menghadapi stres (Tugade \& Frederikson, 2011). Oleh karena itu, hipotesis dalam penelitian ini adalah terdapat hubungan antara dukungan sosial dan regulasi emosi dengan resiliensi keluarga penderita skizofrenia.

\section{METODE}

\section{Partisipan penelitian}

Penelitian ini termasuk dalam penelitian kuantitatif dengan menggunakan desain penelitian survei. Penelitian ini menggunakan data dari 60 anggota keluarga atau caregiver dari individu yang didiagnosis skizofrenia dan pernah menjadi pasien rawat inap di RSJ Dr. Radjiman Wediodiningrat Lawang. Alat pengumpulan data berupa kuesioner diberikan kepada keluarga (ayah dan/atau ibu) sebagai caregiver penderita skizofrenia. Responden yang masih menikah $78 \%$ dan yang tinggal sendirian dalam merawat anaknya yang mengalami gangguan adalah $22 \%$. Tingkat pendidikan paling banyak adalah setingkat SMA yaitu $40 \%$ dan penghasilan yang terbanyak adalah penghasilan antara 1 juta 5 juta yaitu $46 \%$. Terdapat responden dengan tingkat pendidikan $\mathrm{S}_{2}$ sebanyak $13 \%$ dan memiliki penghasilan di atas 10 juta rupiah perbulan sebanyak $12.4 \%$.

\section{Variabel}

Variabel bebas dalam penelitian ini adalah dukungan sosial $\left(\mathrm{X}_{1}\right)$ dan regulasi emosi $\left(\mathrm{X}_{2}\right)$. Kedua variabel bebas ini diukur dengan menggunakan kuesioner. Dukungan sosial diukur menggunakan skala Sosial Support Index yang terdiri dari 17 item dan regulasi emosi diukur dengan Emotion Regulation Questionnaire (CERQ) yang terdiri dari 36 item. Sedangkan variabel terikat dalam penelitian ini adalah resiliensi keluarga $(\mathrm{Y})$ yang diukur dengan menggunakan kuesioner Family Resilience Assessment Scale yang terdiri dari 66 item. 
Selain menggunakan validitas isi, penelitian ini juga menggunakan prosedur validitas item melalui pendekatan konsistensi internal. Validitas item dengan pendekatan konsistensi internal ini menghasilkan suatu indeks validitas item yang umum juga dikenal dengan sebutan indeks daya beda item. Penelitian ini melakukan uji coba terhadap data yang ditabulasikan dengan cara mengkorelasikan antara skor item instrumen dibantu oleh SPSS 17.

\section{HASIL PENELITIAN}

Dari uji Kolmogorov-Smirnov didapatkan nilai signifikansi residual regresi adalah 0.354 ( $\mathrm{p}<0.05$ ), sehingga dapat disimpulkan asumsi normalitas terpenuhi. Kemudian berdasarkan uji multikolinearitas menunjukan baik variabel $\mathrm{X}_{1}$ yaitu dukungan sosial dan variabel $\mathrm{X}_{2}$ yaitu regulasi emosi memiliki nilai VIF 1.o16. Bila nilai VIF lebih dari 10 maka tidak terjadi multikolinearitas yang artinya tidak terdapat hubungan linier yang sangat tinggi antar variabel bebas dalam penelitian ini. dukungan sosial $\left(\mathrm{X}_{1}\right)$ dan regulasi emosi $\left(\mathrm{X}_{2}\right)$ secara simultan terhadap variabel terikat resiliensi keluarga $(\mathrm{Y})$. Hubungan ini dapat ditunjukkan oleh nilai koefisien korelasi berganda $(\mathrm{R})$. Hasil analisis menunjukkan $\mathrm{R}=$ 0.596 ( $\mathrm{p}<0.05$ ). Hal ini menunjukkan hubungan yang cukup kuat antara dukungan sosial, regulasi emosi dan resiliensi keluarga. Hasil analisis menunjukkan bahwa kedua variabel bebas yaitu $\mathrm{X}_{1}$ (dukungan sosial) dan $\mathrm{X}_{2}$ (regulasi emosi), memiliki hubungan signifikan dengan variabel terikat Y (resiliensi keluarga). Kesimpulannya, kedua variabel bebas tersebut dapat dimasukkan dalam model persamaan regresi.

Untuk menguji hipotesis maka dilakukan uji $\mathrm{F}$ dan berdasarkan hasil yang tersaji dalam tabel 2, diketahui bahwa nilai $\mathrm{F}$ hitung yang diperoleh sebesar 15.665 ( $\mathrm{p}<0.05)$. Oleh karena itu, dapat diambil kesimpulan bahwa $\mathrm{H}_{\mathrm{o}}$ ditolak atau $\mathrm{H}_{\mathrm{a}}$ diterima, jadi variabel $\mathrm{X}_{1}$ (dukungan sosial) dan $\mathrm{X}_{2}$ (regulasi emosi) secara simultan berpengaruh signifikan terhadap $\mathrm{Y}$ (resiliensi keluarga).

Tabel 1. Hasil Uji Korelasi Berganda dan Multikolinearitas

\begin{tabular}{lccc}
\hline Variabel Bebas & R & Nilai Tolerance & VIF \\
\hline X1 (dukungan sosial) & 0.596 & 0.984 & 1.016 \\
X2 (regulasi emosi) & & 0.984 & 1.016 \\
\hline
\end{tabular}

Tabel 2. Model Regresi

\begin{tabular}{lccccc}
\hline Variabel & $\beta$ & SE & Uji F & $\mathbf{p}$ & $\mathbf{a R}^{2}$ \\
\hline Resiliensi keluarga & & & & & \\
Konstanta & 52.264 & 0.638 & 15.665 & 0.000 & 0.355 \\
Dukungan Sosial & 0.435 & 0.024 & & 0.000 & \\
Regulasi Emosi & 0.356 & 0.038 & & 0.000 & \\
\hline
\end{tabular}

Penelitian ini ditujukan untuk menguji hipotesis apakah terdapat hubungan antara dukungan sosial dan regulasi emosi terhadap resiliensi keluarga pada penderita skizofrenia. Keeratan hubungan antara variabel bebas
Kemudian untuk mengetahui menentukan kekuatan hubungan antara variabel bebas yang paling dominan dan lebih kuat mempengaruhi variabel terikat maka dilakukan uji koefisien determinasi, yang 
menunjukan hasil sebagai berikut:

Berdasarkan tabel 1 diketahui koefisien korelasi (R) yang dihasilkan sebesar 0.596 yang artinya terdapat hubungan yang kuat antara $\mathrm{X}_{1}$ (dukungan sosial) dan $\mathrm{X}_{2}$ (regulasi emosi) dengan Y (resiliensi keluarga). Sumbangan relatif $\left(a R^{2}\right)$ yang diperoleh sebesar 0.355 , yang berarti varian skor $\mathrm{Y}$ (resiliensi keluarga) disumbang oleh $\mathrm{X}_{1}$ (dukungan sosial) dan $\mathrm{X}_{2}$ (regulasi emosi) sebesar 35.5 persen, sedangkan sisanya dipengaruhi oleh faktor lain selain $\mathrm{X}_{1}$ (dukungan sosial) dan $\mathrm{X}_{2}$ (regulasi emosi).

Untuk menentukan variabel yang paling dominan mempengaruhi Y (resiliensi keluarga), maka dapat dilihat berdasarkan nilai $\beta$ pada masing- masing variabel bebas. Nilai $\beta$ yang paling tinggi merupakan variabel dominan yang sumbangan varian skornya pada variabel $Y$ yang terbesar, yaitu variabel $\mathrm{X}_{1}$ (dukungan sosial) dengan nilai $\beta$ sebesar 0.435 , sedangkan variabel $\mathrm{X}_{2}$ (regulasi emosi) dengan nilai $\beta$ sebesar 0.356.

\section{DISKUSI}

Berdasarkan hasil analisis regresi berganda disimpulkan bahwa dukungan sosial mempunyai pengaruh yang signifikan terhadap resiliensi keluarga penderita skizofrenia. Dukungan sosial menjadi peran penting bagi resiliensi keluarga, sebagaimana disebutkan oleh Elis dan Donovon (2005 dalam Plump, 2011) semakin tinggi tingkat dukungan sosial, maka akan semakin tinggi tingkat resiliensi pada keluarga penderita skizofrenia. Melalui penelitian ini terlihat bahwa dukungan sosial merupakan prediktor yang penting untuk indikator-indikator resiliensi keluarga, antara lain pemaknaan terhadap kejadian musibah dan fleksibilitas dalam keluarga.

Dukungan sosial adalah pertolongan dan dukungan yang diperoleh seseorang dari interaksinya dengan orang lain dimana bantuan tersebut akan dapat menaikkan perasaan positif serta mengangkat harga diri sehingga akan berdampak pada kesejahteraan individu secara umum (Bishop, 1994). Dukungan sosial, dalam penelitian ini terbukti dapat meningkatkan kemampuan resiliensi keluarga. Hal ini sejalan dengan penelitian Plump (2011) terhadap orang tua dari penyandang autistik yang menyebutkan bahwa semakin tinggi tingkat dukungan sosial akan semakin rendah tingkat stres dalam keluarga. Penelitian ini membuktikan dukungan sosial adalah sumberdaya yang penting dalam meminimalkan kesulitan dengan adanya stresor yang kronis yaitu penderita skizofrenia dan meningkatkan adaptasi yang baik.

Dukungan jejaring bisa menjadi faktor protektif dalam pembentukan resiliensi keluarga, sebab dalam jaringan sosial, akan juga didapatkan dukungan informatif yaitu pemberian nasehat, petunjuk, saran-saran atau umpan balik melalui sharing dengan anggota lain dalam kelompok. Hasil penelitian ini juga mendukung penelitian yang dilakukan oleh Pasongh, dkk. (2012) tentang persepsi keluarga mengenai faktor psikososial penyebab skizofrenia. Penulis menemukan bahwa keluarga sering memiliki persepsi yang keliru mengenai gangguan skizofrenia. Melalui penelitian ini dikembangkan penyebab persepsi yang keliru disebabkan karena kurangnya dukungan sosial dalam bentuk dukungan jejaring yang dapat memberikan informasi, umpan balik dan aktivitas yang sesuai untuk penderita skizofrenia. Dukungan jaringan bisa didapatkan melalui interaksi keluarga dengan pihak Rumah Sakit Jiwa melalui aktivitasaktivitas seperti family gathering dan penyuluhan-penyuluhan yang diadakan.

Berdasarkan hasil penelitian, dapat disimpulkan bahwa regulasi emosi mempunyai pengaruh yang signifikan terhadap resiliensi keluarga penderita skizofrenia. Regulasi emosi dengan cara kognitif atau berpikir sangat berhubungan dengan kehidupan manusia dan membantu untuk mengontrol emosi selama atau sesudah mengalami suatu pengalaman yang mengancam atau menekan (Garnefski \& 
Kraaij, 2011). Regulasi emosi, dalam penelitian ini, terbukti dapat meningkatkan resiliensi keluarga.

Penilaian kembali secara positif adalah suatu pemaknaan terhadap suatu kejadian musibah dalam hubungannya dengan pertumbuhan personal (Garnefski \& Kraaiji, 2011). Sedangkan indikator regulasi emosi yang lain memberikan sumbangan yang tidak signifikan terhadap resiliensi keluarga.

Menurut Garnefski dan Kraaij (2011), strategi regulasi emosi yang negatif diantaranya ruminasi, menganggap sebagai malapetaka dan menyalahkan orang lain berhubungan kuat dengan permasalahan-permasalahan emosional diantaranya kecemasan dan kemarahan. Hal ini sejalan dengan pembuktian bahwa indikator di atas memberikan sumbangan secara signifikan terhadap resiliensi keluarga. Selain daripada itu, penggunaan strategi regulasi emosi yang positif, misalnya positive reappraisal akan memudahkan keluarga mentolerir atau menguasai kejadian hidupyang negatif.

Regulasi emosi adalah faktor yang diperlukan untuk mencapai coping yang efektif, dan regulasi emosi secara positif akan mempengaruhi proses berpikir dan perilaku untuk menghadapi kejadian yang negatif (Tugade \& Frederikson, 2006). Dalam penelitian ini, dapat disimpulkan bahwa keluarga penderita skizofrenia perlu melakukan penilaian kembali secara positif terhadap anggota keluarganya yang mengalami skizofrenia untuk dapat meningkatkan resiliensinya.

Berdasarkan hasil analisis data dapat disimpulkan bahwa dukungan sosial dan regulasi emosi memiliki hubungan yang cukup kuat terhadap resiliensi keluarga penderita skizofrenia. Dukungan sosial yang nyata dan regulasi emosi yang positif akan meningkatkan resiliensi keluarga dalam merawat pasien skizofrenia.

Pada dasarnya mikrosistem keluarga diasumsikan merupakan faktor resiko penyebab kekambuhan skizofrenia. Mengasuh dan merawat anggota keluarga yang mengalami skizofrenia merupakan kejadian yang penuh tekanan yang akan mempengaruhi keseimbangan keluarga. Dalam masyarakat yang memberikan stereotype tentang gangguan mental, dimana gangguan mental dikaitkan dengan majik, kesalahan pola asuh atau penyakit kutukan, maka orang tua penderita akan mengalami perasaan penolakan, malu, isolasi, ketakutan dan rasa bersalah. Perasaanperasaan ini akan membuat orang tua menghindar dari aktivitas sosial dan menutup diri tentang penyakit yang menimpa anaknya (Lefley, 1966 dalam Chow, 2011). Kondisi ini akan semakin menjauhkan penderita dari mendapatkan informasi yang akurat dan kesembuhan yang diharapkan.

Sebagai sebuah konstruk, resiliensi layaknya sebuah payung yang terdiri dari banyak konsep-konsep positif menuju suatu adaptasi dalam merespon kejadian-kejadian musibah (Masten \& Obradovich, 2006). Konsep-konsep positif tersebut diantaranya adalah dukungan sosial dan regulasi emosi. Konsep-konsep positif tersebut akan menjadi faktor protektif pembentuk resiliensi diantaranya regulasi diri yang baik, hubungan atau kohesivitas keluarga dan kedekatan hubungan dengan orang lain. Resiliensi keluarga berkaitan dengan adaptasi keluarga yang lebih baik dalam meningkatnya fungsi keluarga dalam merawat anggota keluarganya yang mengalami skizofrenia dan akan meningkat sejalan dengan meningkatnya dukungan sosial dan regulasi emosi yang positif. Melalui model regresi linier yang menjelaskan hubungan antara variabel dukungan sosial dan regulasi emosi terhadap resiliensi keluarga didapatkan interpretasi bahwa resiliensi keluarga akan meningkat sejalan dengan peningkatan dukungan sosial dan regulasi emosi. Sebaliknya, variabel dukungan sosial dan regulasi emosi diperlukan untuk dapat meningkatkan resiliensi keluarga. 


\section{SIMPULAN}

Secara keseluruhan dapat disimpulkan bahwa dukungan sosial dan regulasi emosi merupakan faktor protektif dalam resiliensi keluarga dan merupakan prediktor yang baik untuk fungsi psikologi yang positif setelah kejadian musibah (Garmezy, 2007). Dukungan sosial yang memberikan sumbangan secara signikan terhadap resiliensi keluarga adalah dukungan jaringan. Hal tersebut dapat diinterpretasikan bahwa dengan adanya jaringan yang memadai maka keluarga penderita bisa mendapatkan pengetahuan dan umpan balik mengenai perawatan penyakit tersebut dan bagaimana cara mengatasi kekambuhannya.

Strategi regulasi emosi yang positif akan meningkatkan resiliensi keluarga dalam hal mengembalikan stabilitas respon emosional dalam menghadapi kejadian musibah (Tugade \& Frederikson, 2011). Kompleksitas dari dukungan sosial dan regulasi emosi ini merupakan indeks dari fleksibilitas respon untuk menghadapi kejadian-kejadian dalam kehidupan dan situasi yang sulit berkaitan dengan perawatan gangguan skizofrenia. Peranan keluarga penderita skizofrenia tidak mudah, memerlukan waktu lama dan membutuhkan biaya yang cukup besar.Semakin lama durasi penyakit dan emosi yang naik turun yang disebabkan oleh siklus eksaserbasi dan relaps akan semakin membuat beban bagi keluarga yang merawatnya (Biegel, Sales \& Schulz, 1991 dalam Chow, 2008).

\section{SARAN}

Sejalan dengan kesimpulan yang didapatkan dari penelitian ini, dukungan sosial memiliki hubungan yang lebih kuat dengan resiliensi keluarga dibandingkan regulasi emosi, maka peneliti menyarankan beberapa hal yaitu, bagi keluarga dukungan sosial memberikan insight mengenai penanganan penderita skizofrenia termasuk didalamnya aktivitas yang dapat dilakukan penderita untuk menunjang kesembuhannya dan mengatasi permasalahan apabila terjadi kekambuhan.

Dukungan tersebut selain meningkatkan resiliensi keluarga, juga akan meringankan level caregiver burden yang dirasakan dalam merawat anaknya yang mengalami skizofrenia. Strategi regulasi emosi yang positif, khususnya dengan strategi positive reappraisal keluarga akan dapat meningkatkan kemampuan resiliensi, dimana hal tersebut berarti menunjukkan kemampuan untuk meningkatkan dan memelihara kesehatan dan fungsi psikologisnya dalam menghadapi kejadian musibah. Keluarga dapat mempelajari teknik meregulasi emosi yaitu dengan melakukan penilaian kembali secara positif dengan memperhitungkan sumberdaya yang dimiliki dalam merespon kejadian musibah. Keluarga dapat memanfaatkan sumberdaya untuk berjejaring dan melibatkan diri baik dengan institusi maupun dengan komunitas yang menangani skizofrenia. Melalui pertemuan-pertemuan yang diadakan secara rutin dan berkala, keluarga bisa mendapatkan informasi tentang perawatan skizofrenia secara lebih efektif dari orang yang dipandang cukup kompeten dan berpengalaman.

Selain itu bagi institusi terkait, disarankan untuk mengembangkan intervensi terhadap keluarga pasien dengan menggunakan kerangka resiliensi keluarga. Intervensi ini dapat dilakukan dengan aktivitas seperti, konsultasi keluarga, psikoedukasi berbasis resiliensi melalui penyuluhan secara berkala kepada keluarga pasien dengan materi, adaptasi dengan skizofrenia, stres dan sumberdaya keluarga serta tantangan dalam menghadapi stigma.

Kemudian untuk penelitian selanjutnya disarankan untuk meneliti hubungan antara resiliensi keluarga dengan perjalanan penyakit skizofrenia atau durasi kekambuhan. Selain itu perlu dikembangkan penelitian yang lebih lanjut dengan populasi pasangan dan/atau 
saudara kandung penderita skizofrenia untuk dapat mengeksplorasi konstruk resiliensi keluarga secara lebih mendalam. Penelitian selanjutnya juga diharapkan mengembangkan metodologi dengan menyertakan teknik wawancara mendalam.

\section{PUSTAKA ACUAN}

American Psychiatric Association (2008). Diagnostic and Statistical Manual of Mental Disorder $4^{\text {th }}$ edition. Washington DC: Text Revision.

Day, R.D. (2010), Introduction to Family Process $5{ }^{\text {th }}$ Edition. New York: Routledge.

Garnefski, N. \& Kraaij, V. (2007). The Cognitive Emotion Regulation Questionnaire: Psychometric Feature and Prospective Relationship with Depression and Anxiety in Adult. European Journal of Psychological Assessment, 23(3).

Gonzales-Torres (2010). Stigma and Discrimination towards People with Schizophrenia and Their Family Members: A Qualitative Study with Focus Group. Journal of Social PsychiatryPsychiatry Epidemiology, 42(1):14-23.

Gross, J.J. \& John, O.P. (2003). Individual Differences in Two Emotion Regulation Processes: Implication for Affect, Relationship and Well-Being. Journal of Personality and Social Psychology, 85(2).

Heru, A. \& Dreary, L.M. (2011). Developing Family Resilience in Chronic Psychiatric Ilness, Journal of Medicine E Health, 94(2).

Jones \& Passey. (2009). Family Adaptation, Coping and Resources: Parents of Children with Developmental Disabilities and Behavior Problems, Journal on Developmental Disabilities, 11(1).

Kaplan, H. I., Sadock, B. J. \& Grebb, J. A. (1997). Sinopsis Psikiatri: Ilmu Pengetahuan Perilaku Psikiatri Klinis Jilid 1 (Edisi Ketujuh). Jakarta: Binarupa Aksara.

Kementerian Kesehatan (2007). Laporan Nasional Riset Kesehatan Dasar. Kementerian Kesehatan Republik Indonesia.

Kring, A.M \& Sloan, D.M. (2010). Emotion Regulation and Psychopathology; A Transdiagnostic Approach to Etiology and Treatment. New York: The Guilford Press.

Maria, R. (2013) Sejuta Penduduk Indonesia Berisiko Gangguan Jiwa Berat, www.antaranews.com diakses pada tanggal 19 Mei 2014.

McDonell, M.G., Short, R.A., Berry, B.A. \& Dyck, D.G. (2003) Burden in Schizophrenia Caregivers: Impact of Family Psychoeducation and Awareness of Patient Suicidality. Journal of Family Process, $42(1)$.

Nevid, R. \& Greene. (2003). Abnormal Psychology edisi 5. Jakarta: Erlangga.

Plump, J.C. (2011). The Impact of Social Support and Family Resilience on Parental Stres in Families with A Child Diagnosed with ASD. Disertasi. University of Pennsylvania.

Silderberg, S. (2001).Searching for Family Resilience, Australian Institute of Family Study, Journal of Family Matters, 8(5).

Smet, B. (1994). Psikologi Kesehatan. Jakarta: Penerbit Grasindo.

Stromwall, L.K. \& Robinson, E.A. (1998). When A Family Member Has A Schizophrenic Disorder. American Journal of Orthopsychiatry. 68(4).

Subandi. (dalam penerbitan). The Role of Family Empowerment and Family Resilience on Recovery of Psychosis. Yogyakarta: Gadjah Mada University.

Tugade M.M \& Frederickson, B.L (2006). Regulation of Positive Emotion: Emotion Stragegies That Promotes Resilience. Journal of Happiness Studies, 8, 311-333.

Van Breeda. A.D. (2001) Resilience Theory: A Literature Review. Johanessburg: South African Military Psychological Institute, Social Work Research \& Development.

Walsh, F. (2003) Family Resilience:A Framework for Clinical Practice. Family Process, 42(1). 